\title{
Article \\ Exploring the Adsorption Properties of Zeolite in a New Skin Care Formulation
}

\author{
Massimo Pesando ${ }^{1}$, Veronica Bolzon ${ }^{1}$, Michela Bulfoni ${ }^{2}{ }^{\mathbb{D}}$, Alessandro Nencioni ${ }^{3}$ and Emanuele Nencioni ${ }^{1, *}$ \\ 1 Biofarma Group S.R.L., Via Castelliere 2, Mereto di Tomba, 33036 Udine, Italy; \\ cqsegreteria@biofarmagroup.it (M.P.); microbiologia@biofarmagroup.it (V.B.) \\ 2 Department of Medicine, University of Udine, 33100 Udine, Italy; michela.bulfoni@uniud.it \\ 3 IBSA Institut Biochimique SA, Via del Piano 29, CH-6915 Pambio Noranco, Switzerland; \\ alessandro.nencioni@ibsa.ch \\ * Correspondence: nencioni.emanuele@biofarmagroup.it
}

check for updates

Citation: Pesando, M.; Bolzon, V.; Bulfoni, M.; Nencioni, A.; Nencioni,

E. Exploring the Adsorption

Properties of Zeolite in a New Skin

Care Formulation. Cosmetics 2022, 9 ,

26. https://doi.org/10.3390/

cosmetics 9010026

Academic Editor: Enzo Berardesca

Received: 7 January 2022

Accepted: 16 February 2022

Published: 18 February 2022

Publisher's Note: MDPI stays neutral with regard to jurisdictional claims in published maps and institutional affiliations.

Copyright: (C) 2022 by the authors. Licensee MDPI, Basel, Switzerland. This article is an open access article distributed under the terms and conditions of the Creative Commons Attribution (CC BY) license (https:/ / creativecommons.org/licenses/by/ $4.0 /)$.

\begin{abstract}
Introduction: Zeolites are natural or synthetic aluminosilicates, characterized by a regular and microporous crystalline structure that plays a particularly active role in neutralizing free radicals, screening UV rays and in the adsorption of toxins and heavy metals. Skin is one of the main areas for the accumulation of toxic substances released by environmental pollutants. The biological scavenger activity of zeolite opens a wide spectrum of applications in cosmetics and dermatology. Up to now, there is little evidence related to the use of natural zeolite in cosmetics. Aim: The purpose of this work was to evaluate the ability of zeolite to retain heavy metals in a new skin care formulation, in order to provide a proof of principle of its employment in the field of cosmetics. Materials and Methods: Taking the advantages of spiked samples, we studied the in vitro adsorption properties of zeolite in a new skin care formulation. The removal capacities of Cadmium, Lead, Chromium, Nickel and Cobalt were studied, using the inductively coupled plasma optical emission spectrometry (ICP-OES). First of all, the better concentration of zeolite was defined, testing two different proportions of zeolite, from $1 \%$ to $3 \%$, keeping all other components constant. Then, on the $3 \%$ formulation, the adsorption properties of each single metal were measured. Results and Conclusions: Our preliminary study demonstrated the selectivity of zeolite in retaining Cadmium $(p<0.0001)$, Nickel $(p=0.026)$, in a $3 \%$ zeolite-based formulation. This work provides a proof of principle of zeolite employment in the field of cosmetics. Based on the data collected, our work provides a scientific proof of principle of zeolite employment in the field of cosmetics. New and extensive research will be needed to explore all the potential benefits of zeolite.
\end{abstract}

Keywords: zeolite; cosmetic formulation; heavy metals adsorption; inductively coupled plasma optical emission spectrometry (ICP-OES)

\section{Introduction}

Nanoporous materials are a class of inorganic molecules that have recently become an interesting subject in different areas of chemical, pharmaceutical and cosmetic research [1-4]. Among these materials, zeolites, are natural or synthetic crystalline aluminosilicates, with open 3D framework structures [1,4]. The pore network and the connecting windows occurring in a zeolite structure can absorb gas, metals and other molecules, and facilitate ion exchange [3-6]. Zeolites are basically cation exchangers by a chemical-physical process, where the cation in the crystalline structure is exchanged with the solution ions of similar size and electro-static properties [6,7].

Considering their peculiar structure, zeolites exhibit a great number of interesting biological activities, acting as 'molecular sieves' [3,4,8,9]. Zeolite has excellent properties of absorption, radiation protection, decontamination, detoxification in the human body, but also has the advantage of introducing, by ion exchange, minerals essential for life $[1,10]$. 
Toxic metals are defined by many as "silent killers" because they replace the minerals necessary for life in the body, altering biological functions and structures [10-12].

Zeolites are currently arousing a lot of interest for their absorption properties, able to trap toxins in the crystalline channels $[3,4,12]$.

The positive biological effects of zeolite are widely reported in the scientific literature $[4,8]$. Most of the research concerning the potential use of natural zeolites in the pharmaceutical field was developed from clinoptilolite, arguably the most widespread zeolite in the world. Moreover, In the biomedical field zeolite has been evaluated as an antacid, antidiarrheal, hypocholesterolemic, antidiabetic, antimicrobial, and in anticancer therapies and drugs $[4,8,9,13,14]$.

The detoxificant role of zeolites is also evident in the agro-industrial and in the zootechnical fields, while the clinical diffusion of zeolite as a potential co-adjuvant of toxic chemotherapy appears to be the most relevant but premature $[3,8,9,13-15]$. For example, nontoxic natural zeolite can affect tumour cells proliferation in vitro and might act as an adjuvant in cancer therapy, as confirmed in a study where it was demonstrated that zeolite influences cell viability, cell division, and cellular stress response that results in an anti-proliferative effect and apoptosis induction in vitro. Furthermore, anti-anemia effects and the inhibition of melanoma cells by zeolite has been reported $[9,14,16]$.

The external use of zeolite powder has been shown to be effective in the treatment of skin ulcers, reducing the healing time of wounds and surgical incisions and has some benefits in the treatment of psoriasis $[5,8,13]$. Double-blind clinical studies have found that tissue conditioners, containing silver-exchanging zeolites, have a strong antimicrobial effect [5]. Patients treated with zeolite, administered both internally and topically on the skin, are healed faster and in a greater number than those treated with classic therapies $[8,12,15]$.

In the literature, there is little evidence related to the use of natural zeolite in the field of cosmetics. The accumulation of heavy metals in tissues, chemical molecules that are extremely dangerous for cells, is responsible for the onset of many diseases, such as diabetes, cardiovascular disease, cancer and cell senescence and aging $[9,12]$.

Skin represents the main area of accumulation for toxic substances released by jewellery, air and water pollutants and makeups [10,11,17]. Biological activities open a wide spectrum for zeolites external application in cosmetics and dermatology, in order to safely remove pollutants from the skin $[8,10,11,13]$.

For this reason, it is relevant to examine in depth the mechanisms of action of zeolite that confers, to this nanoporous material, its beneficial properties for skin care.

The purpose of this work was to evaluate the ability of zeolite to retain heavy metals in a new skin care formulation, in order to provide a proof of principle for its employment in the field of cosmetics. Taking the advantages of inductively coupled plasma optical emission spectrometry (ICP-OES), we conducted a "pilot study" that demonstrated the selectivity of zeolite, in retaining certain heavy metals commonly found in the environment.

\section{Materials and Methods}

\subsection{Preparation of Heavy Metals Solution}

In order to test the affinity and the adsorption properties of zeolite, a standard heavy metals solution mix was used. To ensure a titration of each metal with a reasonable level of precision and accuracy, a reference standard solution of heavy metals concentrated at $1000 \mathrm{ppm}$ was employed, in which the metal ions were dissolved in $2 \%$ Nitric acid solution.

The reference standard solutions of Cadmium, Lead, Chromium (Sigma-Aldrich Co., St. Louis, MO, USA), Nickel and Cobalt (Titolchimica S.p.A, Pontecchio Polesine, Italy) were mixed together and diluted in purified water until the final concentration of $4 \mathrm{ppm}$.

\subsection{Spiked Samples Preparation}

To test the Zeolite's metals absorption in a creamy matrix, different spiked samples were made. Two different formulations were tested: $5 \mathrm{~g}$ of cream containing $0.05 \mathrm{~g}$ of Zeolite ( $1 \%$ formulation) and $5 \mathrm{~g}$ of cream containing $0.15 \mathrm{~g}$ of Zeolite ( $3 \%$ formulation). These 
were weighted in different $100 \mathrm{~mL}$ beakers and then $50 \mathrm{~mL}$ of a $4 \mathrm{ppm}$ metals solution was added. In detail, the metals solution was added to a control placebo cream without zeolite and in the test formulation cream (Table 1). Each spiked sample was homogenized using a magnetic stirrer for $1 \mathrm{~h}$ at room temperature. Samples were then filtered using $0.45 \mu \mathrm{m}$ filters in order to remove the cream matrices and the metals entrapped in the matrices.

Table 1. Composition of the zeolite-based cream. Column 1 details the active ingredients, column 2 describes the role of specific components, while column 3 shows references.

\begin{tabular}{|c|c|c|}
\hline Component & Property & Reference \\
\hline Water & Solvent & \\
\hline Xanthan Gum & $\begin{array}{l}\text { Thickening agent, suspending and } \\
\text { stabilizing agent }\end{array}$ & $\begin{array}{l}\text { https:/ / ec.europa.eu/growth/tools-databases/ } \\
\text { cosing/index.cfm?fuseaction=search.details_v2 } \\
\text { \&id=80699 accessed on 7 January } 2022\end{array}$ \\
\hline Pentylene Glycol & Skin conditioning-Miscellaneous & $\begin{array}{l}\text { https:/ / ec.europa.eu/growth/tools-databases / } \\
\text { cosing/index.cfm?fuseaction=search.details_v2 } \\
\text { \&id=58983 accessed on 7 January } 2022\end{array}$ \\
\hline Glycerine & $\begin{array}{c}\text { Skin conditioning-Miscellaneous; } \\
\text { Humectant }\end{array}$ & $\begin{array}{c}\text { https:/ / ec.europa.eu/growth/tools-databases / } \\
\text { cosing/index.cfm?fuseaction=search.details_v2 } \\
\text { \&id=34040 accessed on 7 January } 2022\end{array}$ \\
\hline Hialuronic Acid & $\begin{array}{l}\text { Anti-aging, Moisturizing, } \\
\text { Antioxidant }\end{array}$ & $\begin{array}{l}\text { https:/ / ec.europa.eu/growth/tools-databases / } \\
\text { cosing/index.cfm?fuseaction=search.details_v2 } \\
\quad \text { \&id=34315 accessed on 7 January } 2022\end{array}$ \\
\hline Caprylic Triglyceride & Emollient & $\begin{array}{l}\text { https:/ / ec.europa.eu/growth/tools-databases / } \\
\text { cosing/index.cfm?fuseaction=search.details_v2 } \\
\text { \&id=74815 accessed on 7 January } 2022\end{array}$ \\
\hline Wheat Germ Oil & Skin conditioning agent-Emollient & $\begin{array}{l}\text { https:/ / ec.europa.eu/growth/tools-databases / } \\
\text { cosing/index.cfm?fuseaction=search.details_v2 } \\
\quad \text { \&id=56680 accessed on 7 January } 2022\end{array}$ \\
\hline Shea Butter & $\begin{array}{c}\text { Skin conditioning } \\
\text { agent-Miscellaneous, Emollient and } \\
\text { Moisturizer }\end{array}$ & $\begin{array}{l}\text { https: / / ec.europa.eu/growth/tools-databases / } \\
\text { cosing/index.cfm?fuseaction=search.details_v2 } \\
\text { \&id=56670 accessed on } 7 \text { January } 2022\end{array}$ \\
\hline Cetearyl Alcohol & Thickening agent & $\begin{array}{l}\text { https:/ / ec.europa.eu/growth/tools-databases/ } \\
\text { cosing/index.cfm?fuseaction=search.details_v2 } \\
\text { \&id=75132 accessed on 7 January } 2022\end{array}$ \\
\hline Cetyl Alcohol & Thickening agent & $\begin{array}{l}\text { https:/ / ec.europa.eu/growth/tools-databases / } \\
\text { cosing/index.cfm?fuseaction=search.details_v2 } \\
\quad \text { \&id=32596 accessed on 7 January } 2022\end{array}$ \\
\hline $\begin{array}{l}\text { Mixture of Candelilla, Jojoba, Rice } \\
\text { Bran, Polyglyceryl-3-Esters, } \\
\text { Glyceryl Stearate, Cerearyl Alcohol } \\
\text { and Sodium Stearoyl Lactylate. }\end{array}$ & Anionic emulsifier & $\begin{array}{l}\text { https:/ / ec.europa.eu/growth/tools-databases / } \\
\text { cosing/index.cfm?fuseaction=search.details_v2 } \\
\text { \&id=82338 accessed on 7 January } 2022\end{array}$ \\
\hline Potassium Cetyl Phosphate & Emulsifier & $\begin{array}{l}\text { https: / / ec.europa.eu/growth/tools-databases / } \\
\text { cosing/index.cfm?fuseaction=search.details_v2 } \\
\text { \&id=79512 accessed on } 7 \text { January } 2022\end{array}$ \\
\hline Glyceryl Undecylenate & $\begin{array}{l}\text { Antimicrobial, Emollient and } \\
\text { Emulsifier }\end{array}$ & $\begin{array}{l}\text { https:/ / ec.europa.eu/growth/tools-databases/ } \\
\text { cosing/index.cfm?fuseaction=search.details_v2 } \\
\text { \&id=56331 accessed on 7 January } 2022\end{array}$ \\
\hline Rosmarinus officinalis Leaf extract & antioxidant & $\begin{array}{l}\text { https:/ / ec.europa.eu/growth/tools-databases/ } \\
\text { cosing/index.cfm?fuseaction=search.details_v2 } \\
\text { \&id=79767 accessed on } 7 \text { January } 2022\end{array}$ \\
\hline
\end{tabular}


Table 1. Cont.

\begin{tabular}{|c|c|c|}
\hline Component & Property & Reference \\
\hline \multicolumn{3}{|l|}{ Zeolite Powder } \\
\hline Bibasic Potassium Phosphate & pH stabilizer & $\begin{array}{l}\text { https:/ / ec.europa.eu/growth/tools-databases / } \\
\text { cosing/index.cfm?fuseaction=search.details_v2 } \\
\text { \&id=75739 accessed on } 7 \text { January } 2022\end{array}$ \\
\hline Potassium Phosphate Monobasic & pH stabilizer & $\begin{array}{l}\text { https:/ / ec.europa.eu/growth/tools-databases / } \\
\text { cosing/index.cfm?fuseaction=search.details_v2 } \\
\text { \&id=79722 accessed on 7 January } 2022\end{array}$ \\
\hline
\end{tabular}

Next, $0.5 \mathrm{~g}$ of each filtered sample was weighted in Teflon vials, and $5 \mathrm{~mL}$ of Nitric acid $65 \%, 2 \mathrm{~mL}$ of Hydrochloric acid 37\% (Chemlab NV, Zedelgem, Belgium) along with $2 \mathrm{~mL}$ of Hydrogen peroxide 30\% (Carlo Erba Reagent, Cornaredo, Italy) were added. Those reagents are certified under ISO guidelines, Ph. Eur Metal trace analysis. The Teflon vials were inserted in ceramic guard vials and mounted in a digestor carousel. For the mineralization of the samples, an Anton Paar Multiwave 3000 was used. Then, samples were cooled down and brought to a volume of $30 \mathrm{~mL}$ with Purified water.

\subsection{Definition of the Best Zeolite Concentration}

In a preliminary setting, we evaluated if the concentration of zeolite was proportional to its adsorption efficacy. For this purpose, two different zeolite concentrations were tested, $1 \%$ and $3 \%$, with respect to the final cream composition. Each zeolite percentage (respectively $1 \mathrm{~g}$ and $3 \mathrm{~g} / 100 \mathrm{~g}$ ) was tested in triplicate in 3 independent experiments. Preparation of spiked samples was performed according to previous paragraph's indications.

\subsection{Inductively Coupled Plasma Optical Emission Spectrometry (ICP-OES) Analysis}

Samples were analysed using an ICP-OES Perkin Elmer Optima 8000. For the quantification of heavy metals in our spiked samples a standard curve was created using serially diluted solutions with known metal concentrations. The reference standard of Cadmium, Lead, Chromium, Nickel and Cobalt were diluted to the following four different concentrations: $10 \mathrm{ppb}, 20 \mathrm{ppb}, 50 \mathrm{ppb}$ and $80 \mathrm{ppb}$. By interpolating the test samples to the standard curve an absolute quantification of metals was obtained. Standard and samples were added in $10 \mathrm{ppb}$ of Yttrium as internal standard to normalize flame fluctuance and heat variances caused by matrices.

The ICP-OES settings were as follows: Plasma flow $10 \mathrm{~L} / \mathrm{min}$, Auxiliary flow $0.2 \mathrm{~L} / \mathrm{min}$, Nebulizer flow $0.45 \mathrm{~L} / \mathrm{min}$, Nebulizer pressure $210 \mathrm{kPa}$, Power Watts 1500, View distance 15.0, Plasma View is Axial and Sample Flow Rate $1.50 \mathrm{~mL} / \mathrm{min}$. The wavelengths used were $205.560 \mathrm{~nm}$ for Chromium, $238.892 \mathrm{~nm}$ for Cobalt, $226.502 \mathrm{~nm}$ for Cadmium, $220.353 \mathrm{~nm}$ for Lead, $341.476 \mathrm{~nm}$ for Nickel and $371.029 \mathrm{~nm}$ for Yttrium.

A positive control composed by a heavy metal mix of $4 \mathrm{ppm}$ and a negative control containing only water and hydrochloric acid were used as check-points for each analytical session.

\subsection{Statistical Analysis}

Descriptive statistics for continuous variables are reported as mean \pm standard deviation (SD). Continuous variables comparisons between groups were done using ANOVA One-Way. In particular, the statistical significance of the regression model was checked by Fischer's test (F-test) and by the analysis of variance (ANOVA). The objective of this statistical analysis was to determine any significant differences in heavy metals content of the samples containing different percentages of zeolite. Tuckey comparison was also used to formally test whether the difference between formulations was statistically significant. The statistical evaluations were performed by Minitab version 19 January 2020 and the statistical significance was set at $p<0.05$. 


\section{Results}

Optimization of the Best Zeolite Amount

In order to determine the best concentration of zeolite in the newly designed skin care cream, two different formulations, containing $1 \%$ and $3 \%$ of zeolite, were tested in parallel with a placebo. The main objective of these tests was to estimate if the heavy metal adsorption capacity of zeolite in cream was proportional to its quantity. By using the ICP-OES analyzer, an estimation of the retaining power of Cadmium, Lead, Chromium, Nickel and Cobalt lead was measured. No significant differences in ppm values, calculated for each metal, was found between 1 and 3\% formulations (Table 2), except for Nickel ( $p$ : 0.003) and Cadmium $(p<0.0001)$.

Table 2. The ppm values of each metal measured from placebo, $1 \%$ and $3 \%$ zeolite-based skin cream using ICP-OES analyser.

\begin{tabular}{cccccc}
\hline \multicolumn{5}{c}{ Metal Amount (ppm) \pm SD } \\
\hline $\begin{array}{c}\text { \% of Zeolite } \\
\text { in Cream }\end{array}$ & Nickel & Cadmium & Lead & Chromium & Cobalt \\
\hline 0 & $2.247 \pm 0.55$ & $1.493 \pm 0.31$ & $0.361 \pm 0.21$ & $3.902 \pm 0.28$ & $2.352 \pm 0.76$ \\
1 & $2.295 \pm 0.18$ & $0.129 \pm 0.09$ & $0.101 \pm 0.04$ & $3.858 \pm 0.22$ & $1.562 \pm 0.15$ \\
3 & $1.352 \pm 0.05$ & $0.053 \pm 0.03$ & $0.139 \pm 0.01$ & $3.476 \pm 0.55$ & $1.745 \pm 0.07$ \\
\hline
\end{tabular}

The Tukey pairwise comparison for these two heavy metals (Nickel and Cadmium) allows us to determine whether the mean difference between a pair of groups is statistically significant. Tables 3 and 4 show the confidence interval for the difference between treatment means, placebo, $1 \%$ and $3 \%$ formulations. The 3\% zeolite-based formulation demonstrates a significantly higher adsorption power of Nickel and Cadmium, with respect to placebo $(p$-values <0.05).

Residual diagnostic plots for Nickel and Cadmium indicate that the residuals are normally distributed and homoscedastic, with respect to treatments, fitted values, and run order, as required in the ANOVA method.

Table 3. Tukey simultaneous tests for differences of means for Nickel.

\begin{tabular}{cccccc}
\hline $\begin{array}{c}\text { Difference } \\
\text { of Levels }\end{array}$ & $\begin{array}{c}\text { Difference } \\
\text { of Means }\end{array}$ & $\begin{array}{c}\text { SE of } \\
\text { Difference }\end{array}$ & $\mathbf{9 5 \% ~ C I}$ & $\boldsymbol{t}$-Value & $\begin{array}{c}\text { Adjusted } \\
\boldsymbol{p} \text {-Value }\end{array}$ \\
\hline $1-0$ & 0.048 & 0.299 & $(-0.773 ; 0.869)$ & 0.16 & 0.986 \\
$3-0$ & -0.895 & 0.299 & $(-1.716 ;-0.074)$ & -2.99 & 0.033 \\
$3-1$ & -0.943 & 0.354 & $(-1.914 ; 0.028)$ & -2.66 & 0.057 \\
\hline
\end{tabular}

Individual confidence level $=98.00 \%$.

Table 4. Tukey simultaneous tests for differences of means for Cadmium.

\begin{tabular}{cccccc}
\hline $\begin{array}{c}\text { Difference } \\
\text { of Levels }\end{array}$ & $\begin{array}{c}\text { Difference } \\
\text { of Means }\end{array}$ & $\begin{array}{c}\text { SE of } \\
\text { Difference }\end{array}$ & $\mathbf{9 5 \% ~ C I}$ & $\boldsymbol{t}$-Value & $\begin{array}{c}\text { Adjusted } \\
\boldsymbol{p} \text {-Value }\end{array}$ \\
\hline $1-0$ & -1.364 & 0.165 & $(-1.818 ;-0.910)$ & -8.24 & 0.000 \\
$3-0$ & -1.440 & 0.165 & $(-1.894 ;-0.986)$ & -8.70 & 0.000 \\
$3-1$ & -0.076 & 0.196 & $(-0.613 ; 0.461)$ & -0.39 & 0.921 \\
\hline
\end{tabular}

Individual confidence level $=98.00 \%$.

As seen from Table 2, the skin care cream containing 3\% zeolite showed an advantage in holding Nickel, Cadmium, Cobalt and Lead, with respect to placebo. ANOVA analyses were performed and results are reported in Table 5 . 
Table 5. Analysis of variance (ANOVA) results for each heavy metal.

\begin{tabular}{ccc}
\hline Heavy Metal & $f$-Value & $p$-Value \\
\hline Nickel & 7.41 & 0.026 \\
Cadmium & 62.37 & 0.000 \\
Lead & 3.17 & 0.113 \\
Chromium & 2.82 & 0.132 \\
Cobalt & 1.64 & 0.237 \\
\hline
\end{tabular}

Statistical analysis confirmed the significant residual ppm of these heavy metals (Nickel $p=0.026$; Cadmium $p<0.0001$ ), between placebo and zeolite-based cream. The ANOVA output for Cadmium showed that the F statistic was large (62.37), indicating that there were significant differences between the treatments. Furthermore, The ANOVA output for Nickel showed that the F statistic was 7.41, meaning that there were significant differences between the treatments and the Tukey pairwise comparison, which shows that intervals of the treatment mean, obtained from the formulation containing $3 \%$ of zeolite and placebo, were significantly different.

\section{Discussion}

Zeolite is frequently used as an effective adsorbent and has gained interest among researchers; mainly because its sorption properties provide a combination of ion exchange and molecular sieve properties $[1,10,13]$. Despite the great interest in ion exchange with zeolite, there is very little evidence on the elimination properties of certain heavy metals from cosmetic formulations. The removal of Cadmium, Lead, Chromium, Nickel and Cobalt onto zeolite, as a function of their concentrations, was studied in this preliminary work, in order to define its potential in cosmetic formulations. By varying the zeolite concentration from $1 \%$ to $3 \%$, keeping all other components of the creamy formulation constant, a better adsorption of Nickel and Cadmium was obtained in our skin care cream. The efficiency of zeolite in removing or filtering out contaminants depends on several factors, including the composition of the zeolite, $\mathrm{pH}$ value, types of contaminants present and their concentrations [18]. Many of these elements have already been discussed in the literature, but not ever in the field of cosmetics $[6,7,10,11]$. In the present study the assessment of zeolite's properties was carried out for all experiments at room temperature (RT). We tried to simulate standard conditions in the use of skin cosmetics. The physiological response of the skin tends to fluctuate, within a normal range, a few degrees above and below that point (more or less). Therefore, we are confident that testing the adsorption properties in a normal environmental condition in vitro, could be a good starting point from which to start to evaluate the effects in vivo.

In fact, among cosmetic targets, skin represents the main area exposed of external aggressors, such as pollution, dirt, and other particulate matter. In this context, the biological activities of zeolite open a wide spectrum of external application, thanks to its ability to absorb, hold, release and exchange different chemicals and ions in the body $[5,8,15]$.

Based on the data collected, it can be speculated that our work provides a scientific proof of principle for zeolite employment in the field of cosmetics. Furthermore, several important questions are still unanswered; for example, the molecular mechanism that increases the heavy metal and toxic metabolites retention [12]. Considering our results, an anion absorption mechanism seems to be at the base of its action against metals. In fact, zeolite addition in creamy preparations showed an encouraging effect on Cadmium $(p<0.0001)$, Nickel $(p=0.026)$, but was not evident for Lead, Chromium and Cobalt in vitro models, such as spiked samples. The pollutant-binding, detoxifying and regulating properties of zeolite could be applied in the form of skin cream, as demonstrated in our preliminary in vitro study. 


\section{Conclusions}

This preliminary study confirms the adsorption capacity of zeolite in a new skin care formulation. At physiological temperature, a 3\% zeolite formulation showed a significant performance in adsorbing Cadmium $(p<0.0001)$ and Nickel $(p=0.026)$ in creamy cosmetics. The application of zeolite in skin care preparations could have a great impact on the adsorption specificity and capacity in removing heavy metals derived from the environment. Different formulations offer the possibility to make tailored zeolite-based preparations for targeted clinical applications. In fact, zeolite appears to be promising for wound healing, blood coagulating, antibacterial properties and skin regeneration $[4,8,14,15]$. Furthermore, possibilities for designing zeolitic structures by the computational simulation methods could enhance and amplify the zeolitic performance and applications [19-21].

However, despite our preliminary work, suggesting the benefits of zeolite in cosmetics' production, new and extensive research will be needed to explore all the potential benefits on human health. For example, further studies could be done on a mixture of zeolite with other adsorbent active principles, in order to create a better tailored product for customers.

Author Contributions: M.P. and E.N., conceptualization, data curation; M.P. and V.B. methodology and formal analysis; E.N. and A.N. methodology and interpretation of results; E.N., M.B. and A.N. writing-review and editing. All authors have read and agreed to the published version of the manuscript.

Funding: This work was supported by Biofarma S.R.L.

Institutional Review Board Statement: Not applicable.

Informed Consent Statement: Not applicable.

Data Availability Statement: The authors confirm that all relevant data are included in the article and materials are available on request.

Acknowledgments: We are grateful to Anna Piasentin from the R\&D Biofarma Team for her precious contribution in the cream formulation.

Conflicts of Interest: The authors declare no conflict of interest.

\section{References}

1. Moshoeshoe, M.; Nadiye-Tabbiruka, M.S.; Obuseng, V. A Review of the Chemistry, Structure, Properties and Applications of Zeolites. Am. J. Mater. Sci. 2017, 7, 196-221.

2. The World Book Encyclopedia Year Book 2004; World Book, Inc.: Chicago, IL, USA, 2004.

3. Derakhshankhah, H.; Jafari, S.; Sarvari, S.; Barzegari, E.; Moakedi, F.; Ghorbani, M.; Varnamkhasti, B.S.; Jaymand, M.; Izadi, Z.; Tayebi, L. Biomedical Applications of Zeolitic Nanoparticles, with an Emphasis on Medical Interventions. Int. J. Nanomed. 2020, 15, 363-386. [CrossRef] [PubMed]

4. Serati-Nouri, H.; Jafari, A.; Roshangar, L.; Dadashpour, M.; Pilehvar-Soltanahmadi, Y.; Zarghami, N. Biomedical applications of zeolite-based materials: A review. Mater. Sci. Eng. C Mater. Biol. Appl. 2020, 116, 111225. [CrossRef] [PubMed]

5. An, S.-W.; Jeong, Y.-C.; Cho, H.-H.; Park, J.-W. Adsorption of $\mathrm{NH}_{4}^{+}-\mathrm{N}$ and E. coli onto $\mathrm{Mg}^{2+}$-modified zeolites. Environ. Earth Sci. 2016, 75, 437. [CrossRef]

6. Ćurković, L.; Cerjan-Stefanović, Š.; Filipan, T. Metal ion exchange by natural and modified zeolites. Water Res. 1997, 31, 1379-1382. [CrossRef]

7. Guo, H.; Zhang, X.Y.; Liu, J.L. Ion-exchange capability for ammonium removal using zeolite modified by potassium permanganate. Chem. Eng. Trans. 2016, 55, 163-168. [CrossRef]

8. Bacakova, L.; Vandrovcova, M.; Kopova, I.; Jirka, I. Applications of zeolites in biotechnology and medicine-A review. Biomater. Sci. 2018, 6, 974-989. [CrossRef]

9. Hao, J.; Stavljenić Milašin, I.; Batu Eken, Z.; Mravak-Stipetic, M.; Pavelić, K.; Ozer, F. Effects of Zeolite as a Drug Delivery System on Cancer Therapy: A Systematic Review. Molecules 2021, 26, 6196. [CrossRef]

10. Zamzow, M.J.; Eichbaum, B.R.; Sandgren, K.R.; Shanks, D.E. Removal of Heavy Metals and Other Cations from Wastewater Using Zeolites. Sep. Sci. Technol. 1990, 25, 1555-1569. [CrossRef]

11. Taamneh, Y.; Sharadqah, S. The removal of heavy metals from aqueous solution using natural Jordanian zeolite. Appl. Water Sci. 2017, 7, 2021-2028. [CrossRef]

12. Luch, A. (Ed.) Molecular, Clinical and Environmental Toxicology: Volume 3: Environmental Toxicology; Springer: Basel, Switzerland, 2012. [CrossRef] 
13. Mastinu, A.; Kumar, A.; Maccarinelli, G.; Bonini, S.A.; Premoli, M.; Aria, F.; Gianoncelli, A.; Memo, M. Zeolite Clinoptilolite: Therapeutic Virtues of an Ancient Mineral. Molecules 2019, 24, 1517. [CrossRef]

14. Pavelić, K.; Hadžija, M.; Bedrica, L.; Pavelić, J.; Dikic, I.; Katić, M.; Kralj, M.; Bosnar, M.H.; Kapitanović, S.; Poljak-Blaži, M.; et al. Natural zeolite clinoptilolite: New adjuvant in anticancer therapy. J. Mol. Med. 2001, 78, 708-720. [CrossRef]

15. Khodadadi Yazdi, M.; Zarrintaj, P.; Hosseiniamoli, H.; Mashhadzadeh, A.H.; Saeb, M.R.; Ramsey, J.D.; Ganjali, M.R.; Mozafari, M. Zeolites for theranostic applications. J. Mater. Chem. B 2020, 8, 5992-6012. [CrossRef] [PubMed]

16. Shin, Y.J.; Han, C.-S.; Lee, C.S.; Kim, H.-S.; Ko, S.-H.; Hwang, S.K.; Shin, J.W.; Ye, S.-K.; Chung, M.-H. Zeolite 4A, a Synthetic Silicate, Suppresses Melanogenesis through the Degradation of Microphthalmia-Associated Transcription Factor by Extracellular Signal-Regulated Kinase Activation in B16F10 Melanoma Cells. Biol. Pharm. Bull. 2010, 33, 72-76. [CrossRef] [PubMed]

17. Hua, M.; Zhang, S.; Pan, B.; Zhang, W.; Lv, L.; Zhang, Q. Heavy metal removal from water/wastewater by nanosized metal oxides: A review. J. Hazard. Mater. 2012, 211-212, 317-331. [CrossRef] [PubMed]

18. Echeverría, J.C.; Zarranz, I.; Estella, J.; Garrido, J.J. Simultaneous effect of $\mathrm{pH}$, temperature, ionic strength, and initial concentration on the retention of lead on illite. Appl. Clay Sci. 2005, 30, 103-115. [CrossRef]

19. Eroglu, N.; Emekci, M.; Athanassiou, C.G. Applications of natural zeolites on agriculture and food production. J. Sci. Food Agric. 2017, 97, 3487-3499. [CrossRef] [PubMed]

20. Vejmelková, E.; Koňáková, D.; Kulovaná, T.; Keppert, M.; Žumár, J.; Rovnanikova, P.; Kersner, Z.; Sedlmajer, M.; Černý, R. Engineering properties of concrete containing natural zeolite as supplementary cementitious material: Strength, toughness, durability, and hygrothermal performance. Cem. Concr. Compos. 2015, 55, 259-267. [CrossRef]

21. Ding, Y.; Sartaj, M. Statistical analysis and optimization of ammonia removal from aqueous solution by zeolite using factorial design and response surface methodology. J. Environ. Chem. Eng. 2015, 3, 807-814. [CrossRef] 